Kamete, A.Y. (2013) On handling urban informality in southern Africa. Geografiska Annaler: Series B, Human Geography, 95 (1). pp. 17-31. ISSN 0435-3684

Copyright (C) 2013 The Authors.

A copy can be downloaded for personal non-commercial research or study, without prior permission or charge

The content must not be changed in any way or reproduced in any format or medium without the formal permission of the copyright holder(s)

When referring to this work, full bibliographic details must be given

http://eprints.gla.ac.uk/77200/

Deposited on: 27 March 2013

Enlighten - Research publications by members of the University of Glasgow http://eprints.gla.ac.uk 


\title{
ON HANDLING URBAN INFORMALITY IN SOUTHERN AFRICA1
}

\author{
Amin Y. Kamete ${ }^{凶}$ \\ Urban Studies, School of Social and Political Sciences \\ University of Glasgow
}

\section{DETAILS OF DEFINITIVE VERSION}

Kamete, A.Y. (2013). On handling urban informality in southern Africa. Geografiska Annaler: Series B, Human Geography, 95(1): 17-31. doi: 10.1111/geob.12007

\begin{abstract}
In this paper I reconsider the handling of urban informality by urban planning and management systems in southern Africa. I argue that authorities have a fetish about formality and that this is fuelled by an obsession with urban modernity. I stress that the desired city, largely inspired by Western notions of modernity, has not been and cannot be realised. Using illustrative cases of top-down interventions, I highlight and interrogate three strategies that authorities have deployed to handle informality in an effort to create or defend the modern city. I suggest that the fetish is built upon a desire for an urban modernity based on a concept of formal order that the authorities believe cannot coexist with the 'disorder' and spatial 'unruliness' of informality. I question the authorities' conviction that informality is an abomination that needs to be 'converted', dislocated or annihilated. I conclude that the very configuration of urban governance and socio-economic systems in the region, like the rest of sub-Saharan Africa, renders informality inevitable and its eradication impossible.
\end{abstract}

Keywords: modern city; formality; informality; planning; southern Africa; Zimbabwe.

\section{Introduction}

In many ways urban planning and management systems in many countries in sub-Saharan Africa (SSA) betray a fixation with the quest for order: one of modernity's "impossible tasks . . and that made modernity into what it is" (Bauman, 1993, p. 4). Those tasked with governing SSA's growing cities are obsessed with ideals of order, orderliness and conformity which are characteristic of modernity. Having modelled their urban planning systems and practices on those of the former colonial masters (Legg, 2007), many authorities have sought to impose an

\footnotetext{
${ }^{1}$ The definitive version is available at http://onlinelibrary.wiley.com/doi/10.1111/geob.12007/abstract

${ }^{\bowtie}$ Contact: Urban Studies, School of Social and Political Sciences, University of Glasgow, 29 Bute Gardens, Glasgow, G12 8RS, United Kingdom. Email: amini.kamete@glasgow.ac.uk; Tel: +44 1413305682.
} 
urban order highly reminiscent of that of the former colonial metropole (Rakodi, 2006). This pursuit has tended to purge and/or exclude local forms of production, consumption and accumulation that bear no resemblance to those obtaining in the colonial metropole. This should not be surprising: urban areas are perceived "as reservoirs of . . modernity and progress amidst a host of threats from their uncivilized 'outsides"” (Popke and Ballard, 2004, p. 101)

However, the exclusion of certain ways of life and livelihood practices has not meant their permanent demise. In much of urban SSA, deliberate marginalisation in urban policy and planning practice has not translated into disappearance on the ground. As rapid urbanisation has set in and formal economies have failed to cope, socio-economic conditions have progressively become unpalatable and 'poor-unfriendly'. These exigencies and their innumerable strands together constituted a growing and enduring crisis: the urban crisis (Stren and White, 1989). The composite crisis has hit all aspects of urban life, including and particularly the satisfaction of basic needs. It is largely in response to this crisis that the subterranean and officially detested ways of life and modes of practice have swamped many cities in SSA. Nevertheless, it appears the authorities, backed by their professionalised bureaucracies, have refused to acknowledge, let alone accept, this reality. Most have clung onto their dream of a western-inspired urban modernity (Swilling et al, 2002), prompting a long-time scholar of urban SSA to conclude that planners, who are instrumental in spatialising the search for urban modernity, have "little understanding about how the poor survive" (Rakodi, 1993, p. 207). In a way, however, planners and related bureaucrats do understand how the poor survive; they are just hostile to what they regard as spatialised deviance.

In this paper I focus on a specific geographic region of SSA: southern Africa. It is in this part of SSA that we find some of the most spirited quests of the orderly modern city on the continent. I contend that city authorities in southern Africa have a real fetish about formality. Southern Africa has three countries where top-down approaches in the governance of place (Ambert and Feldman, 2002), which can rightly be characterised as "entirely modernist" (Watson, 2002, p. 35), can be easily identified: Zimbabwe, South Africa and Namibia. It is my argument that although other countries seem to be less zealous and their planning systems less potent, the logic of modernity and the underlying motivation for the quest of the modern city are there: which accounts for similarities in the methods of handling informality. As shown in the cases below, 
the logics and motivation are easy to detect when they erupt — albeit sporadically-at some key moments such as when the modern city has to be flaunted to visitors or when informality becomes intolerable.

I offer a critique of the authorities' perception and handling of urban informality as evidenced by many of the top-down strategies that are designed to 'de-informalise', relocate, eradicate or 'repressively tolerate' informality. In the next section, I frame the authorities' fixation with formality. I examine the city that the authorities desire and contrast it with the actually existing city. This is followed by a presentation and detailed critique of three illustrative cases from Zimbabwe which show 'de-informalisation', rehabilitation/dislocation, and 'repressive tolerance' in action. Before rounding up the discussion, I argue that in some ways Zimbabwe is an extreme but not unique case by outlining similar cases from cities across southern Africa.

It is not my argument that the desire for urban modernity is the sole motivation for everything the authorities do in the cities; nor is it my contention that every quest for the modern city is 'bad'. There are some other motives such as health and safety, environmental protection, the neutralisation of opposition spaces and genuine desire for the wellbeing of the population. Admittedly, there are programmes that have 'worked' for the poor, such as those relating to the participatory upgrading of informal settlements (see Odendaal, 2007; Beall and Todes, 2004). Of course, most of these are socially inclusive, decentralised, participatory and democratic, as opposed to the 'normal' expert-centred, centralised, top-down, authoritarian programmes (cf. UN-HABITAT, 2008; AAPS, 2012). Arguably, even some of these 'sensible' programmes are driven by a conception of the 'urban' that is rooted in modernity, what with their focus on “'modern' and 'civilised' styles of consumption, including the desire to own a 'proper' house" (Robins, 2002, p. 512).

What I am taking issue with here is the predominance of the desire for urban modernity in the handling of informality. My focus is on unilateral, centralised, state-driven, top-down interventions that have caused inconvenience, pain, and injury to less privileged urbanites. Even here, there might be a genuine desire to 'improve' the lot of the people. Be that as it may, 'good' results and seemingly altruistic reasons do not exorcise the underlying desire for the modern city and the many forms of physical and epistemic violence that often accompany its quest and 
defence. As some commentators have observed, modernity does have a 'dark side' (Llobera 1988; Yiftachel, 2002); needless to say, it also has a 'bright side'.

While concerned with southern Africa, this discussion addresses a phenomenon that is relevant in human geography and development studies in the global South in general and sub-Saharan Africa in particular. Studies on informality in the global South abound. A lot of attention has traditionally been given to Latin America (Castells and Portes 1989) and the trend continues (Blunch et al, 2007). Recently, Asia and the Middle East have been the focus of illuminating studies, with a lot of emphasis on what Roy (2011) calls "subaltern urbanism". There is an increasing volume of work on Africa examining various aspects of informality among them informal workers (Lindell, 2010); insurgency (Meth, 2010); taxation (Stern and Barbour, 2005); and the conceptualisation and treatment of informality in academic and policy circles (Potts, 2008). This paper adds to the stocks of knowledge built up by these studies by explicitly interrogating governmental responses to the phenomenon of urban informality in southern Africa.

In contrast to 'subaltern urbanism', the discussion peers into the motivations, rationality and rationalisations of the authorities in different countries in the region. It addresses an important phenomenon that should be of interest to human geography in general and the geography of development in particular. It is also relevant to the applied side of geography: the planning and governance of urban space. The governance of informality discussed here is by no means unique to southern Africa. States in Latin America, the Middle East and Asia everywhere respond to informality in various ways (cf. Roy and AlSayyad, 2004; Ghertner, 2010). This paper complements these works by adding a southern African dimension.

Writing about Mexico City Canclini (2010, p. 81) posits that "the imagined city [is] always a rough draft". Unsurprisingly, cities imagined by "people who . . . view the city from the heights of power" (Canclini, 2008, p. 83) inevitably experience a "deficient realization of their calling" (p. 81) to modernity. Caldeira (2008, p. 51) makes similar observations about São Paulo as she highlights "the optimistic imaginaries anchored in the notions of progress, development and growth" (aka urban modernity) which have made it difficult for the authorities to manage the 
city's present configurations. These are some of the sentiments I am trying to critically elaborate, modify, extend and illustrate with respect to southern Africa.

By exploring the motivations behind the authorities' the bid to formalise informality and critiquing the modernist rationalisations underpinning their actions, the paper raises questions about top-down policies that are fixated with formalisation in various ways, not always to improve the lives of the people, but sometimes to pander to the whims of the authorities. These concerns go beyond southern Africa. Through its explicitly critical approach this work adds to and/or unsettles some approaches, perspectives and conclusions in studies of informality in various geographic regions of the global South (De Soto, 1989; Blunch et al, 2007; Holston, 2008; Simone, 2005a; Meagher, 2010; Prakash, 2010; Roy 2010, 2011). In complementing these works, this paper not only exposes the failures of the quests for urban modernity, but also explains why the desired city can never be realised. Significantly, it also systematically peers deeper into the dark side of this relentless quest even where it appears to be benign and even altruistic.

\section{The desired city ... and the actually existing city}

Authorities $^{2}$ in many countries in SSA betray a desire to build 'modern' cities: that is, cities that are ordered and orderly, are aesthetically pleasing, and are amenable to intervention through "design, manipulation, management [and] engineering" (Bauman, 1993, p. 7). To this end, they have designed "multifaceted development and governance interventions" (Simone, 2002b, p. 296) to attain the modern city, to maintain and sustain it, and to deal with obstacles to its attainment or existence. Undoubtedly, the major inspiration — and therefore the standard - for the desired 'urban modernity' is the Western city, itself a paragon of transformation from premodern times (Berman, 1982). From colonial times when sub-Saharan African cities were "places for European living" (Wekwete, 1994, p. 5), to the post-colonial era when they have

\footnotetext{
${ }^{2}$ I use the term 'authorities' to denote collectively the group of people with official legal power to make or enforce rules and regulations in urban areas. They include urban councils and professionalised bureaucracies responsible for planning and managing areas under their jurisdiction. Of course, the authorities are not a coherent unit. Thus reference to the 'authorities' should not imply that they are a unified whole which always acts in unison. There are contradictions and tensions between and within the state's constituent parts. Further, conflicts occasioned by and played through asymmetrical power relations frequently occur between and within state institutions and between the multiplicity of actors - political (elected or appointed) and professional-located in various state agencies. It is not my intention to unpack 'the authorities' to discern how their attitudes are formed and exercised, or whether and how they vary between the actors.
} 
purportedly become places for all, the traditions of Western modernity have been unquestioningly incorporated into the planning and management of cities, all in an effort "to constitute modern cities" (Swilling et al, 2002, p. 307).

This unbridled pursuit has had significant repercussions on cities. A myriad of laws and regulations have been crafted and enforced to support and defend the quest for the modern city (Abdoul, 2005, p. 9). Consequently, the production of urban spaces and the designation of legal and permissible occupation and uses for those spaces strongly suggest that the permissible and acceptable ways of life and spatial practices are those that conform to strict Western-inspired precepts (cf. Devas, 1993, p. 64-5). Through strict categorizations, non-conforming practices are declared 'out of place' and have to go (cf. Cresswell, 1996). Sometimes there may be practices that deviate from the norm but are deemed (temporarily) tolerable, maybe because they are viewed as not being beyond redemption or are deemed not to be dangerously threatening to the urban order. In all cases, however, the declaration of what is tolerable and intolerable is the prerogative of the authorities who are entitled to plan urban space "so that it can be named, weighed up and elaborated," in order to create "a spatial order in which all life is laid out" (Amin and Thrift, 2002, p. 109).

The official prescription of spatial propriety inevitably means that some ways of life and livelihood practices are frowned upon or outlawed altogether. History shows that these officially designated improprieties come to be perceived as such because they do not conform to official standards of normality. They mainly have to do with the satisfaction of basic needs in the 'modernised' urban cash economy. The official designation of what constitutes normal, acceptable and decent urban activities - such as what type of housing and livelihood practices are regarded as proper-has been helped by the dualistic classification of urban economic activities into the 'formal' and 'informal' sector (Bromley, 1978).

Informality is a phenomenon that the economy, to which it is commonly restricted, thanks to Hart's original theorising of economic informality with its emphasis on amenability to official enumeration (Hart, 1970; 1973; cf. Gerry and Bromley, 1977; Moser 1978). In these economistic conceptualisations, the informal sector is viewed as "an unregulated microentrepreneurial sector" (Maloney, 1999, p. 1159; cf. Castells and Portes, 1989; Samers, 2005). However, in the cities of 
the global South, it is more fruitful to speak of urban informality which characterises all “practices and activities . . . operating beyond what the state would define as 'normal' and/or which exist contrary to stipulations laid out in law" (Donaghy, 2002, p. 271). Roy perceptively views informality as "much more than an economic sector" but as "a mode of the production of space". In contrast, formality is a defining feature of "activities and practices which the state defines as legitimate and/or which are carried out in accordance with official laws and regulations" (Donaghy, 2002, p. 271).

Informality permeates all aspects of the urban system, including housing and land occupation (Roy, 2003), commerce, production and work (Maloney, 1999), and even the public sphere and political processes (Mizstal, 2001; 2005). For this reason, in this paper, I deploy Watson's very useful conceptualisation of informality as encompassing "forms of income generation, forms of settlement and housing, and forms of negotiating life in the city" (Watson, 2009, p. 157). According to some estimates, informality accounts for the provision of three quarters of basic needs in the majority of African cities (Simone, 2005b, p. 3), and 60 percent of all urban jobs are in the 'informal sector' (UN-HABITAT, 2010, p. xxv). So pervasive, entrenched and organised is informality in these cities that it is apposite to talk of "systems of informality" (Roy, 2003, p. 468).

In much of SSA, particularly southern Africa, the urban modernity being sought by the authorities is one in which informality has no place. Informality is seen as belonging to "a backward sector that [reflects] badly on the country's attempt to modernize" (Thomas, 2001, p. 6). To the authorities, modernising the country entails effacing the 'backwardness' encapsulated in informality. To this end, most cities have a battery of measures that are supposed to stem, restrict or tame informality, which, according to the authorities, is "both undesirable and illegal" (UN-HABITAT, 2010, p. xxvi). However, the problem with this pugnacity and the cocktail of hostile measures that have been designed to help attain the desired modern city with its emphasis on formal order is that they have created significant constraints in key sectors of the urban system. With respect to housing, for example, Rakodi (1993, p. 207) observes that the planning system - a key vehicle in realising and maintaining the desired level of modernity - places constraints on the supply of serviced land and housing, adversely affecting urbanites at the bottom rungs of the socio-economic ladder. These afflicted ones are by far the majority 
(Wekwete, 1994, p. 23); they are "desperately poor, chronically unemployed . . . and economic outcasts" (Berman, 1982, p. 304-305). And they still have to satisfy their basic needs within the severely constricted possibilities.

Consequently, the grafting of Western city planning and management practices onto African cities in the quest for urban modernity has had a dual adversity on urban places: marginalising those who cannot meet the stringent requirements, and, simultaneously, spawning subterranean livelihood practices and ways of life. The authorities have failed to "either eliminate the sector or improve the livelihoods of informal entrepreneurs" (UN-HABITAT, 2010, p. xxvi). Not surprisingly, the actually existing city in SSA is a far cry from the vision of the authorities. This explains why Swilling et al (2002, p. 307) scathingly describe African cities as "failed simulations of external notions of modernity". The poor majority have found it difficult, if not impossible, to make it in the city should they choose to adhere to the cocktail of exclusionary regulatory and legislative controls imposed by the authorities. Referring to these 'informals' as "the urban disenfranchised", Bayat (2000, p. 552) notes that they "find it difficult to function, live and work, within the modernising cultural and economic systems characterised by market discipline, contracts, exchange value, speed and bureaucratic rationale". Many of them have been forced to find ways of surviving outside the exacting official prescriptions, "beyond the purview of state regulation" (Lindell, 2010, p. 1).

Having repeatedly failed to attain the desired city, the authorities in much of urban SSA have not engaged in serious and open-minded reflection to grasp the peculiarities of the actually lived city (cf Rakodi, 1993, p. 207); nor have they adjusted their desires, believing as they do, that the dream is still attainable despite the numerous notable misses. Instead, in a determined effort to preserve the fleeting glimpses of urban modernity they believe they have attained, the authorities have implemented (counter)measures, some of them "restrictive and violent" (Lindell, 2010, p. 3 ), to rein in errant ways of life and improper livelihood practices. Thus, not only do the authorities view these undesirable ways as obstacles to the attainment of the (still) desired city, but they also label them a threat to the little that has purportedly been gained.

In this way, the authorities' endless pursuit of the desired city all too often becomes a nightmare for the 'nonconformist' majority in the actually existing city. The forced relocation of vendors in 
2003 in Maputo, Mozambique (Kamete and Lindell, 2010); Zimbabwe's 2005 urban 'clean-up' campaign (Potts, 2006; Kamete, 2010); and the eviction of street vendors in major urban centres of Malawi in 2006 (Sabola, 2006) are recent examples of such delusions of an elitist minority that have degenerated into nightmares for many. In all these cases, the authorities seem to have rejected the notion that informality possesses the "ability to act as a coping mechanism where corporate capitalism does not . . . deliver the goods" (Samers, 2005, p. 875), what with the continuing fragility of many African economies (King, 2001, p. 98).

The official (counter)measures are, however, not all firm and decisive; nor are they uniform in time and space. Sometimes, for various-mainly political and logistical-reasons, urban authorities have been known to practice something akin to "repressive tolerance", which is no more than "a partisan goal, a subversive liberating notion and practice ... serving the cause of oppression" (Marcuse, 1969, p. 95). They let the nonconformists go on with their lives amidst a surfeit of condemnations, denunciations and threats, liberally complemented with the imposition of tough conditions. In some cases, especially where the systems are riddled with corruption, incompetence or incapacity, or where the unwelcome ways are deemed to not be totally unbearable nuisances - because, for example, they are not occupying prime urban spaces or are not visibly intrusive - the authorities have chosen to (temporarily) turn a blind eye (see Gueye, 2001; Kamete and Lindell, 2010). In other cases, some 'enlightened' authorities have tried to work with these nonconforming 'outsiders' to minimise the perceived damage they wrought on the dream city or to help some units of the informal sector shed off informality and 'graduate' into the decent and acceptable formal sector by taking on the desirable characteristics of formality (see Vaa and Tranberg-Hansen, 2004).

\section{In search of the modern city in Zimbabwe}

\section{Dealing with informality}

This section provides three illustrative cases on how the national and local authorities in Zimbabwe have handled urban informality, especially where it is characterised by spatial nonconformity. The cases are a squatter settlement, street people, and unauthorised housing and tuck shops. The three cases contain vivid elements of the fetishization of formality by the authorities. Detailed critiques will be provided in subsequent sections. 
Admittedly, Zimbabwe is an extreme case in terms of the scale, pace and viciousness of some of the campaigns such as Operation Murambatsvina/Restore Order (OM/RO). But the country is certainly not unique in several key aspects critically explored here: a stubborn faith in the logic of modernity; authorities who seek urban modernity; and top-down authoritarian strategies used to deal with informality. The rationalisations and modus operandi are similar in the cases that will be presented from other parts of southern Africa.

That the official approach to informality is broadly similar across SSA was confirmed by a communiqué by the Association of African Planning Schools (AAPS), an international association of African planning academics and educators. The Association decried the "the persistent tendency towards the clearance of 'slums' and informal settlements" observing that "many governments demonstrate a persistent tendency to view slums and informal settlements ... as blighted problems to be eradicated through forcible eviction and demolition" (AAPS, 2012).

\section{'De-informalisation': Epworth squatter settlement}

Situated $10 \mathrm{~km}$ outside the eastern boundary of Harare, Epworth is "the only autonomous squatter settlement to have been tolerated in post-independence Zimbabwe" (Butcher, 1989, p. 10). This is probably due to complexities arising from claims of ownership by the second generation squatters, and the fact that the land belonged to a religious organisation, the Methodist Missionary Trust (MMT). Official tolerance may also have been motivated by the presence of many refugees who had fled from the war-torn rural areas during the liberation war. Instead of the usual knee-jerk reaction to demolish the settlement and evict the squatters, in 1983 authorities made a decision to upgrade the area, now home to some 25,000 people.

A planning consultant identified the issues that made the settlement anathema to those who desired a modern city (Butcher, 1989). One of these was rampant land speculation, a practice worsened by criminal elements. The other problem related to the seemingly unlimited subdivision of land parcels, which in turn led to overcrowding with over 40 people living on a tiny stand. Having noted this, the consultant echoed the views of the authorities when she noted, "Clearly some form of control over land tenure and the sale of property . . . need to be enforced" (Butcher, 1989, p. 11; emphasis added). Yet another problem was on the threat of water pollution 
made more acute by the fact that surface and ground water drains through the area flowing into some of Harare's bulk water supplies. Another threat, and the bane of the authorities' quest for the modern city, was the almost total absence of services and community facilities. The squatters had "no publicly provided utilities such as water, sewerage, electricity or rubbish collection" (Butcher, 1989, p. 12), this in addition to educational, commercial and transport and health facilities that fell way below the officially stipulated standards.

The in situ upgrading consisted of transferring land from the MMT to the state. The components of the upgrading programme were all aimed at correcting the situation. To this end, the officials had two main goals for the upgrading (Butcher, 1989, p. 14). The first was to control further settlement by registering all residents while simultaneously imposing a freeze on further building; the second goal was to improve the quality of the settlement by addressing the infrastructural and community service deficiencies. The realisation of these goals inevitably entailed the extension of Harare's urban planning and management framework to the area. Notably, Epworth would be incorporated into greater Harare only after it had ceased to be a squatter settlement and after it had been upgraded to City of Harare standards.

\section{Dislocation (and some 'rehabilitation'): street people}

By the beginning of the new millennium the number of street people-people who sleep and work on the streets - in Harare's Central Business District (CBD) had reached over 10,000 (Kamete, 2002a). They consisted of street children and adult vagrants. By engaging in generating livelihoods in ways that were illegal or bordered on the illicit, and taking over prime urban spaces for 'work' or 'housing', these homeless people were an obstacle to urban modernity. They were also endangering what had been achieved, or was in the process of being achieved. The choice of the city centre as their living and operational zone placed them in a situation where they were visible and constant reminders of the failures of urban policy. Their ever-increasing number was a symbol of failures in the quest for the desired city.

In the first few years of independence, the authorities crafted an aggressive response to these 'maladies'. In 1983, barely three years after independence, in a major nationwide operation codenamed 'Operation Chinyavada [Scorpion]', hundreds of prostitutes and unaccompanied women were rounded up carted away to prisons, detention centres and resettlement areas 
(Rupiya, 2005, p. 117). The operation was intended to rid urban centres of ways of life (prostitution and vagrancy) that were incompatible with the authorities' perception of acceptable lifestyles and practices in the modern city. Before the end of the 1980s, the forcible evictions and relocations had been expanded to encompass all street people. By the year 2000, the authorities had 'perfected' their act (MPSLSW, 1999). In a typical raid, officially referred to as a 'clean-up' operation, the authorities would swoop on street children, suspected prostitutes and adult vagrants. After giving the non-submissive ones a thorough beating, they would hastily herd them into government and council trucks, drive them some 50-150 km away from the city and dump them in the middle of nowhere (see Maponga, 2006). At times, the authorities would place the children and youth among the captives in education or training centres and some other "places of safety" (MPSLSW, 1999) where they were supposed to learn some useful skills, the idea being that they would eventually be 'reintegrated' into society (MPSLSW, 2000). In all cases, the rehabilitation was supposed to happen outside the city. Readmission into the city would be a result of that rehabilitation. Continued residency would be contingent upon conformity.

\section{Eradication: unauthorised structures}

By the turn of the century, some 70 percent of Harare's population of 1.4 million were lodgers (tenants with informal rental arrangements) (Mubvami and Hall, 2000). Some 500,000 of them were housed in unauthorised structures mainly in the high-density residential areas (HDRAs) (Justgiving, 2001). These structures consisted of backyard shacks, unauthorised extensions and conversions (see Tipple, 2000). By then, in the HDRAs, backyard shacks outnumbered legal structures by a factor of five to one (Kamete, 2002a). Also littered across all HDRAs were illegal tuck shops and business structures. All the unauthorised structures and the uses to which they were being put violated every conceivable operative regulation: planning, tax, building, public health, safety, labour and environmental sanitation, to mention but a few.

Undoubtedly, as regards the authorities' single-minded pursuit of the modern city, this phenomenon put spanners in the works. It also blighted the image of the city. The overloading of services, caused by overcrowding, itself partly a result of the mushrooming of illegal structures, has always been cited by the authorities as one of the reasons why they cannot perform their duties effectively (City of Harare, 2001; 2005). This assertion is not without substance. For example, at the close of the century, Mbare, the oldest HDRA in Harare, had an average of 13 
families occupying one 200-square metre stand originally intended for a single family of no more than six people (Shackdwellers' International, 2000). Some stands had as much as 40 people living on them. Some of the structures encroached onto municipal roads (Mashavira, 1999), wreaking havoc on efforts by Harare City Council (HCC) to build a modern city. The overcrowded families shared one toilet, one water point, and one mains outlet. In the hostels in the same suburb an average of eight people shared one room of no more than $10 \mathrm{~m}^{2}$. All this was in contravention of the provisions of the city's building, public health, safety and sanitation bylaws - core instruments in the quest for and defence of the modern city.

In March 2001, without notice, HCC mounted a predawn raid, bulldozing illegal structures with the explicit intention of eradicating what were officially perceived as eyesores. By the time the blitz was dramatically halted due to a combination of public outcries and central government intervention, over 500 shacks had been razed to the ground. Even after grudgingly halting the blitz, the local authority did not revisit its hostile policy and intentions. It just announced a unilateral moratorium, publicly refusing to recognise, let alone regularise, the structures despite pressure from civil society. The acting chairperson of the commission (the state-appointed municipal authority) defiantly stressed:

Harare is being reduced to a town of cabins and backyard shacks and the commission is not going to allow that ... Our resolution to demolish illegal structures still stands and we are not going to stop at anything. Residents should know that there are by-laws they have to abide by and that the commission has no sympathy for whoever violates the by-laws (City of Harare, 2001).

True to their intransigence, for the following three and a half years, during which the uneasy moratorium was in place, the city authorities did not relent in their hostility towards unauthorised structures. Threats, condemnations and blame continued to be poured on the offending structures and those benefiting from them. Eventually in 2005, through the world-(in)famous clean-up operation ('Operation Murambatsvina/Restore Order') the authorities finally eradicated the structures. In Harare, some 38,065 illegal residential structures-home to more than 35,000 families-were destroyed, this in addition to 8,945 informal business structures that were demolished (Tibaijuka, 2005, p. 85). 


\section{Handling informality: a scrutiny}

The preceding cases suggest that having repeatedly failed to achieve the city of their dreams, and having decided to blame burgeoning informality for what to all intents and purposes is an inevitable failure, authorities have responded to informality in a variety of methods. The response has been motivated by two impulses: defending what has been gained and removing obstacles to the continued pursuit of the modern city. In this case, Zimbabwe well illustrates the handling of urban informality by authorities in SSA, particularly southern Africa. After a century of colonial settler-initiated urbanisation, the authorities in Zimbabwe have managed to craft what is undoubtedly the toughest urban planning and management system in SSA (see Wekwete, 1988; Rakodi, 1995); and they have not been found wanting in actively demonstrating their seriousness about attaining and protecting urban modernity. To this end, they have unrelentingly dealt with informality in two principal active strategies, namely, 'forced conversion' and frontal aggression, and one passive strategy, namely, 'repressive tolerance'.

\section{A forced conversion: de-informalisation}

De-informalisation entails the "formalisation of the informal" (Robins, 2002, p. 537). It is some kind of exorcism, a process of shedding informality. Forced conversion is a top-down strategy, a practice where the authorities attempt to make offending practices reform by shedding some 'bad' traits and replacing them with 'good' ones. For authorities, this is a path to eventual redemption: formality. In the case of Epworth, authorities sought to 'convert' the squatter settlement into something acceptable and decent enough to be assimilated into modern Harare. To this end, upgrading would entail improvements and controls that would eventually lead to regularisation, whereupon the plots and houses would finally be accepted as normal. The ultimate trophy of these "utopian visions of modern living" (Robins, 2002, p. 513) would be legalisation. This would bring the settlement in line with the precepts of a desirable modern capitalist land and housing market when people

This transformation is a 'forced conversion' in the sense that it was top-down and most of the intended 'beneficiaries' neither volunteered nor accepted the upgrading. Some even resisted it. One of the reasons is that it imposed a cost on them, making the now-regulated settlement inaccessible to and unaffordable for the poor and/or new entrants into the urban housing and land markets (cf. Simone, 2005b, p. 21). Additionally, the installation of standard infrastructure 
caused some disruption as some houses were destroyed and the affected residents had to be relocated to an overspill against their will.

A more vivid case of forced conversion is the putative 'upgrading' of 'street kids' into proper citizens through eviction and punishment followed by education and (re)training. The reference by authorities to eventual 'reintegration' (Kamete, 2002b) confirms this. By the time they would be deemed fit to be 'reintegrated' into mainstream urban society, the 'converted' youth would have adopted some desirable traits befitting useful members of society (MPSLSW, 2000).

In de-informalising some ways of living and practices, the authorities' intention is to make a perceived threat less potent, to reduce the danger to the pursuit of their dream. In addition to making the realisation of the modern city less arduous and more certain, the authorities would also be defending the patches of urban modernity they had purportedly attained. Also, the coercive transformation would, in one swoop, be an achievement in the sense that an entire abnormality would be transformed into something fit for, and useful to, the desired city. This is normalisation-discipline through the imposition of strict norms - a distinctive feature of modern power (Foucault, 1995).

\section{Frontal aggression: eradication and dislocation}

Frontal aggression entails a full-fledged onslaught on the identified nuisances. The authorities directly attack these with the explicit intention of permanently eradicating them so that they would neither cause more injury to the modern city nor hinder its pursuit. This is the drastic action the authorities took against unauthorised structures in the HDRAs. The principal reason for eradication and dislocation is that the nature as well as the demographic and spatial extent of the problem would have made rehabilitation or forced conversion complex and expensive. In The anathema was beyond redemption.

Furthermore, the illegal structures were far too degenerate to be incorporated into the dream. They had become a pathology that needed to be removed for the path to the desired city to be cleared of troublesome obstacles and for supposed gains to be guarded. The same can be said of the dislocation of street people. Even for the youth and children who qualified for rehabilitation, the rehabilitation process could not take place in situ. It had to happen outside the city. Dislocation was necessary to attain and/or preserve the modern city. The dumping of these 
'nuisances' in places far away from the city was obviously meant to discourage these undesirables from returning to the city to cause further disruption to the dream and reverse gains.

\section{Temporary reprieve: 'repressive tolerance'}

Repressive tolerance is an 'intervening' measure. It is an unofficial response that characterises the authorities' handing of all types of informality. It happens when authorities take no action against offending ways of life and livelihood practices. By tolerating what amounts to abominations, the authorities are not signalling acceptance or permission; they are simply taking no action. This tolerance is repressive as it serves "the cause of oppression" (Marcuse, 1969, p. 95). The authorities use this unilateral moratorium to regroup or to set the stage for another onslaught. During this oppressive calm, like a sword of Damocles the authorities' hostile intentions will always be hanging over the officially defined abominations. To signal their

unabated hostility and ill-intentions, during this repressive moratorium the authorities endlessly condemn, blame and threaten the nuisances, thereby reminding them that they are 'out of place' (see Cresswell, 1996)

Repressive tolerance characterises periods of relative calm for the nonconformists. As noted above, this is not born out of charitable intentions on the part of the authorities. To quote, Bauman (1993, p. 8), what the authorities are saying is: "You are abominable, but I, being generous, shall let you live". In any case, history shows that forced conversions and frontal aggression are never conclusive enough. The authorities know that they cannot mount a sustained and continuous campaign of attacks or forced conversions. Consequently, periodic unilateral truces are pragmatic, if not inevitable. That is why for some periods street people go on with their way of life and illegal structures continue to be of service to those benefitting from them. There are even extended periods of clam when some certainty creeps in and a false sense of security takes hold. That is precisely why, when authorities finally launch their 'blitzkrieg' without notice, the victims are always caught flatfooted, having let down their guard, fooled by the false sense of security, and lulled by a precarious stability.

\section{Is Zimbabwe really unique?}

The handling of informality discussed above is not unique to Zimbabwe. Authorities throughout southern Africa have used similar methods, though sometimes with less zeal and violence than 
Zimbabwe. Forced conversions have been known to happen across southern Africa. Among the most illustrative is the removal of street traders from the streets into council-built markets in Lusaka which started in 1999. This was obviously meant to 'de-informalise' the street traders' livelihood practices by helping them behave like formal trading outlets that have a fixed locality with all services in line with public health and planning codes. There were elements of rehabilitation in this strategy. A Zambian scholar confirms this when she points out that one of the aims of the so-called "New Management Model" was "the rehabilitation and rationalisation of . . . urban markets in the major cities" (Nchito, 2002, emphasis added). Just like their formal sector counterparts, these rehabilitated and converted traders would now be subject to bureaucratic controls and all the costs and benefits that come with formality, among them rates and access to credit.

Still on forced conversion, in southern Africa there is no shortage of top-down technocratic settlement upgrading programmes similar to Epworth. For example, in Zambia, upgrading is a typical top-down technocratic approach. It is the "Government . . . [that] has decided to upgrade [informal settlements]" (Simposya, 2010). The law provides that the local authority may declare some unplanned settlements as improvement areas, giving the authorities the power to 'improve' substandard settlement in a technical process that entails redesigning the settlements with the ultimate aim of improving housing units and other socioeconomic facilities and services (Simposya, 2010). Though the ultimate aim is "to improve the quality of life of the residents of unplanned settlements", one scholar notes that "squatter upgrading in Zambia has not been able to improve the socio-economic facilities and services in the affected areas" (Simposya, 2010). As noted by Chileshe in the upgrading of Bauleni, an informal settlement near Lusaka, one reason is that "[b]uilding standards established during the colonial administration continued to be in force and therefore affordable housing was still a problem" (Chileshe, undated). This is not surprising: it is not the lives of the people that matter, but the modern city: titling and the installation of services and infrastructure would be an integral part of the programme, just as in Epworth. Notwithstanding the vaunted participatory approach, there is no doubt that the programme's standard of normality and improvement was formality. Getting there would necessarily entail extensive de-informalisation. 
The Namibian authorities are honest about their intentions for upgrading 'extra-legal' settlements. According to Mooya and Cloete (2007, p. 12), "local authorities accept the informal settlers [repressive tolerance?], but would like to formalise the areas so that the residents get formal rights and the local authority can collect taxes and charges for utilities". The top-down approach in Namibia is tightly regulated with the law prescribing "elaborate procedures for the creation of . . land hold titles, and for upgrading these" Mooya and Cloete, 2007, p. 14). These tight prescriptions are obviously intended to 'de-informalise' slums by remoulding them in the image of the formal city.

Eradication through eviction was what the Malawian authorities went for when, in April 2006, they decreed that street traders should move from the streets. The combative authorities "ordered vendors off the streets of major towns and cities in the country . . . come rain, come sunshine" (Sabola, 2006). The evicted vendors were dumped away from the city centre and ended up operating far from the CBD. Clearly, the authorities felt uncomfortable with the taking over of the city centres by informality (Kayuni and Tambulasi, 2009). To them the vendors and their businesses were eyesores damaging the image of the modern city (see Jimu, 2004). So they had to go.

The Malawi case also illustrates instances of repressive tolerance. There was a period of peace; but typical of the authorities' hostilities, they made it clear that their animosity was still extant. The repressive tolerance made some people believe that government was showing "reluctance to kick-out the vendors who crowded the streets," which made some of them conclude that the state's incessant threats and calls for vendors to move were "mere political rhetoric" (Sabola, 2006). However, the tolerance was bound to be revoked. In April 2006, the authorities finally got their way - this despite the vendors' defiance and their declaration that "they were ready to die in the streets".

In Botswana - praised for being a beacon of stability, prosperity and democracy — rehabilitation is part of the toolkit for handling street children. Here, it is acknowledged that "there is a relationship between poverty, delinquency and being a street child" (Campbell and Ntsabane, 1995). Predictably, one of the proposed responses to this 'problem' is to "develop a training and rehabilitation centre for street children" (Campbell and Ntsabane, 1995; emphasis mine). 
In cases reminiscent of Zimbabwean-style dislocation and eradication, in Durban, South Africa, “policemen rounded [street kids] up daily and dumped them on the city's outskirts, often on busy freeways or at unregistered shelters" (Laganparsad, 2010). The policeman reportedly told the youth to go back where they came from because Durban was dirty because of them (Laganparsad, 2010). Significantly, this incident happened in the run-up to the World Cup. ${ }^{3}$ The authorities insist that these regular round-ups, which have often happened in Durban before major international conferences or sports events are necessary 'street cleaning exercises' (Tolsi, 2010).

In post-war Angola, peace and oil money have allowed the authorities to modernise the cities partly through dislocation. Like elsewhere in Southern Africa, in this oil-rich country, the city is essential to reconstruction and modernisation. Perhaps unsurprisingly, in Luanda "forced evictions to make way for ... development have targeted the poorest neighbourhoods" (Amnesty International, 2009, p. 3). It goes without saying that in the top-down exercise, it is the poor neighbourhoods, the eyesores, which are under the authorities' radar. Signs of failed modernity such as Luanda's Cidadania neighbourhood have to be eradicated, to make way for the modern city. Inevitably, the poor residents of these informal settlements have been "forcibly relocated to areas far from their schools and places of work" (Amnesty International, 2009, p. 3). In another operation, elegantly codenamed 'Operation Combat and Demolition of Shacks and Anarchic Constructions in the Municipality of Lubango', the Angolan authorities demolished more than 2000 houses, relocating more than 3000 families, as part of an official clearance programme to make way for public construction or infrastructure projects (Croese, 2010).

The preceding cases demonstrate some similarities in the way authorities in southern Africa have handled urban informality in their backyard. The list of similar cases across southern Africa would impress anyone enamoured with the modernist project. They include the removal of vendors from the streets of Maputo, Mozambique prior to an African Union summit in 2003 (Lindell, 2008; Kamete and Lindell, 2010); the "sporadic harassment and eviction" as well as relocation and rehabilitation of street vendors in Maseru, Lesotho in 2001 (Leduka, 2003); the 'de-informalisation' and rehabilitation of squatter settlements in Mbabane, Swaziland (SDI,

\footnotetext{
${ }^{3}$ According to Laganparsad (2010), a local NGO "said the police's methods were inhumane. The organisation said the welfare of the children was more important than Durban's image". The organisation observed that "removing children for the World Cup was not about child protection but about cleaning up the streets".
} 
2007); and the relocation of residents of Marconi Beam, a squatter settlement, to a 'modern' Joe Slovo Park, Cape Town, in post-apartheid South Africa (Robins, 2002).

\section{Conclusion}

The authorities' quest for urban systems that are alien to a significant proportion of the urbanites has so far been an unrealised pursuit. Evidence suggests that it might be unrealisable. One of the major reasons for this is that the urban planning, policy and management practices that champion the pursuit for the modern city have been "highly deterministic and far removed from the dynamic socio-economic changes occurring in urban centres" (Wekwete, 1994, p. 23). The unbridgeable discrepancy between the desire and the enduring contextual realities largely accounts for the failure of the authorities' spirited attempt to attain the modern city. While it is true that urban planning and management is about improvements from the existing situation, one should ask the question: What makes formality superior to informality? That informality spawns social ills and crimes is not a convincing explanation.

The equating of informality with illegality is an unfortunate result of "too great an emphasis on the regulatory perspective ... [that] has identified informality with illegality" (Tokman, 2001, p. 46). The ILO's original conceptual interpretation which defined informality in opposition to formality, though done in good faith (ILO, 1972; see Tokman, 2001), does not help matters. It stresses the different nature of informality vis-à-vis formality (cf. Castells and Portes, 1989). In modernist planning and management practices, where difference to what is defined as the norm is coterminous with badness, this can only strengthen the case of the authorities' desire to tame informality (see Sandercock, 1998). For what it is worth, informality is not illegality. The two are conceptually different (Castells and Portes, 1989, p. 14-15).

Predictably, the authorities will argue that informality is neither totally innocent, nor always a victim. They will cite what they consider to be misdemeanours, vices and infractions of urban life and practices dominated by informality. The list might include 'bad' behaviour such as street-children and beggars inconveniencing people going about their business in the CBD. They could finger the 'informal sector' for vices such as smuggling and prostitution. Like Zimbabwe's top banker, they could blame informality for sabotaging the economy and crippling the treasury by evading taxes, smuggling goods out of and into the country, and creating a 
parallel market (Kamete, 2009). Urban managers could feel that people in the informal sector are free-riders, benefiting from urban services they do not pay for. These could also accuse informality of making everybody's life difficult by causing or hastening the collapse of urban infrastructure and services through overcrowding, illegal connections to utilities, illegal structures and unauthorised extensions. In this and other matters, the authorities could also accuse the informal sector of causing environmental damage.

However, any roll of shame based on the preceding list of infractions should also include features of urban life and practices dominated by formality. Instances of tax evasion, smuggling, corruption, environmental damage and free-riding do happen-sometimes in more concentrated form-in the formal sector. But the authorities have neither questioned nor contested the acceptability, let alone the existence, of formality. And they have not pulled out all the stops to destroy it or forcibly convert it into something else. Rather, where specific culprits have been identified, such as in environmental or economic crimes, appropriate penal codes have been invoked individually applied. Significantly, there have been cases where the authorities have invested a lot of resources in efforts to make formal sector culprits behave better without shedding their formality. Public campaigns and active help for individual elements of formality are not unheard of. These official responses are based on the assumption that it is not formalityand ultimately its very existence - that is the problem, but some elements of formality or units within the formal sector. There is no justification why things should be different when it comes to informality. Really, there is simply no logic or justice in citing some wrongs to justify the wholesale wiping out or 'de-informalisation' of informality and then suddenly change the rules when it comes to formality.

For the authorities' pursuit of the modern city to be regarded as sane just, and for the authorities' animosity to informality to be viewed as no more than a mindless and dangerous fantasy, the authorities should demonstrate that making informality history will make cities better, not only for a privileged minority that can afford to dream because it is not engrossed in the logistics of day-to-day survival, but also for the majority of urbanites, who happen to be poor (Swilling et al, 2002). 
Further, what should raise questions is the authorities' single-minded pursuit of the elusive city despite having repeatedly drawn blanks. Is it prudent to keep searching for the modern city modelled along Western traditions of modernity, when that search, costly though it has proved to be, still manages to reach dead-ends? The authorities' legendary "refusal to acknowledge and address the whole city as a particular African organism" (Swilling et al, 2002, p. 309), bespeaks a conviction that there is no alternative to the adopted ideal. This in a way explains why, after a century of urbanisation and over a quarter century of independence, the authorities in Zimbabwe are still bent on bidding good riddance to ways of life and modes of practice that do not fit into the official schema of a modern city. This also explains why authorities have invested a lot in strategies like forced conversion, frontal attacks and repressive tolerance. It sheds light on the puzzle as to why they choose to be oblivious to the heavy toll exacted by their quest on street people, lodgers, enterprising homeowners and squatters.

Condemning the rounding up of street children, the Combined Harare Residents Association (CHRA) described it as not having "logical justification and was typical of a facile and symptom-based approach to urban governance - get rid of the manifestations of a problem and hope the cause will disappear!" (CHRA, 2004). It is tempting to extend this scathing criticism to all facets of the official quest for the modern city. It appears the authorities choose to view informality as an unreasonable and unforgivable characteristic because it is unnecessary and disruptive. Their hostility suggests they regard those satisfying their basic necessities outside formal systems as scoundrels who have chosen a way of life that is damaging to the city.

Not many authorities publicly acknowledge that the growth of informality is in many ways a direct response to the inability of the formality to deliver land, housing and jobs. Most of them do not admit to the multiple failures of local government and unsuitable governance systems; nor do they admit that informality has for decades been cushioning the poor against these vagaries, and ironically, even protecting them from the ire of the poor. Very few subscribe to the notion that taking refugee in informality is not necessarily an evil choice, but an honest response to real constraints.

So it is that the quest for the orderly and ordered city has had some debilitating side-effects. The authorities' penchant for control has meant that southern African cities remain stuck with 
managerial forms of urban governance and politics, while putative "post-modern urban societies" elsewhere have for long been witnessing "a rapid evolution of urban politics and governance from traditional managerial forms to more entrepreneurial forms" (Gospodini, 2006, p. 311; see also Cross, 2000; Harvey, 1989). Southern African urban authorities are stuck in a mindset that holds that a lot of good comes from criminalisation, control, policing and regulation, all done with the explicit intention of creating cities that are exclusive to formality. They are drowning in the conviction that all waywardness - defined as everything that does not fit into the official scheme of things, however unrealistic, unjustifiable or unjust - can be tamed or forcibly hounded out. As a result, save for a few urban centres, most of them in South Africa, the vast majority of national and urban local authorities are not concerned about making their cities competitive and productive. They are not worried about creating cities that are liveable and suitable for the majority of their citizens. Theirs is an unfettered preoccupation with creating modern cities.

But the very configuration of governance and socio-economic systems in urban SSA makes informality inevitable. As noted by Cross (2000, p. 30),

Informality often appears in the grey area between the imposition of laws . . . and the lack of enforcement of those laws due to a combination of the inability of the state to do so and the ability of the poor and relatively unorganized to thwart enforcement.

Indeed, for all their determination, the authorities have not struck a decisive blow at the heart of informality, not because they do not want to, but because they simply cannot. In the presence of enduring adversity and the exclusionary nature of formality, coupled with incapacity and lack of creativity in urban governance systems - this in the absence of viable alternatives for the affected majority-informality is set to become a permanent feature of African cities, even those overseen by the toughest urban planning and management systems. What complicates the situation for the authorities is that the growth and resilience of informality is being aided by another phenomenon, namely, the informalisation of formality (cf. King, 2001, p. 98; Friedman et al, 2000). 


\section{References}

AAPS (Association of African Planning Schools) (2012): 'An appeal for new approaches to managing urban informalities in Africa'. Communiqué to African government agencies, national planning bodies, development agencies, and media entities. Cape Town, 24 January.

ABDOUL, M. (2005): 'Urban development and urban informalities: Pikine, Senegal', in SIMONE, A. and ABOUHANI, A. (eds): Urban Africa: Changing Contours of Survival in the City. CODESRIA/Zed Books, Dakar/London, pp. 235-260.

AMBERT, C. and FELDMAN, M. (2002): 'Are IDP's barking up the wrong tree? A story of planning, budgeting, alignment and decentralisation'. Paper presented at the Planning Africa 2002 Conference, Durban 18-20 September. Available at http://www.saplanners.org.za/SAPC/papers/final\%20paper\%20planafrica.pdf (accessed 21 November 2005)

AMIN, A. and THRIFT, N. (2002): Cities: Reimagining the Urban. Polity Press, Cambridge.

AMNESTY INTERNATIONAL (2009): Unjust, Unlawful, Unacceptable Forced Evictions in Angola. Amnesty International, London.

BAUMAN, Z. (1993): Modernity and Ambivalence. Polity Press, Cambridge.

BAYAT, A. (2000): "From "dangerous classes" to "quiet rebels", International Sociology 15(3): $533-557$.

BEALL, J., and TODES, A. (2004): 'Gender and integrated area development projects: lessons from Cato Manor, Durban', Cities 21(4): 301-310

BERMAN, M. (1982): All That Is Solid Melts into Air: The Experience of Modernity. Penguin, New York.

BLUNCH, N.-H., CANAGARAJAH, S., and RAJU, D. (2001): The Informal Sector Revisited: A Synthesis across Space and Time (Social Protection Discussion Paper No. 0119). World Bank, Washington, DC. 
BROMLEY, R. (1978): 'Introduction - The urban informal sector: why is it worth discussing?' World Development 6(9-10): 1033-1039.

BUTCHER, C. (1989): Low-income housing in Zimbabwe: a case study of the Epworth squatter upgrading programme. RUP Occasional Paper 6. University of Zimbabwe, Harare.

CALDEIRA, T.P.R. (2008): 'From modernism to neoliberalism in São Paulo: reconfiguring the city and its citizens', in HUYSSEN, A. (ed): Other Cities, Other Worlds: Urban Imaginaries in a Globalizing Age. Duke University Press, Durham/London, pp. 51-77.

CAMPBELL, E.K. and NTSABANE, T. (1995): Street Children in Gaborone, Botswana: Causes and Policy Implications. Union for African Population Studies, Accra.

CANCLINI, N.G. (2008): 'Mexico City 2010', in HUYSSEN A. (ed), Other Cities, Other Worlds: Urban Imaginaries in a Globalizing Age. Durham/London: Duke University Press, pp. 79-95.

CASTELLS, M. and PORTES, A. (1989): 'World underneath: the origins, dynamics and effects of the informal economy', in PORTES, A. CASTELLS, M. and BENTON L.A. (eds): The Informal Economy: Studies in Advanced and Less Developed Countries. Johns Hopkins University Press, Baltimore, pp. 11-37.

CHILESHE, L. (undated): 'The case of Bauleni upgrading, Lusaka, Zambia' [online resource]. URL http://www.bestpractices.org/learning/casebooks/hic2/zambia.pdf [Accessed 13 May $2011]$.

CHRA (Combined Harare Residents Association) (2004): 'The persecution of the homeless in Harare'. Press Statement, Harare, 2 March.

CITY OF HARARE (2001): 'Statement by the Chairperson of Harare City Commission'. Harare, 29 March.

CITY OF HARARE (2005): 'Speech by the Chairperson of the Harare Commission Cde Sekesai Makwavarara on the occasion of the official launch of "Operation Murambatsvina"”. Harare, 19 May. 
CRESSWELL, T. (1996): In Place/Out of Place: Geography, Ideology and Transgression. University of Minnesota Press, Minneapolis.

CROESE, S. (2010): 'Angola: Rebuilding by demolishing - the politics of national reconstruction' [online resource]. URL http://www.pambazuka.org/en/category/features/63298 [Accessed 20 May 2011].

DE SOTO, H. (1989): The Other Path: The Invisible Revolution in the Third World. Harper \& Row, New York

DONAGHY, M. (2002): 'Formality and informality in offshore financial centres', Social Identities 8(2): 271-286.

FOUCAUlT, M. (1995): Discipline and Punish: The Birth of the Prison. Vintage, New York.

FRIEDMAN, E., JOHNSON, S., KAUFMANN D., and ZOIDO-LOBATON, P. (2000): 'Dodging the grabbing hand: the determinants of unofficial activity in 69 countries', Journal of Public Economics 76(3): 459-493.

GERRY, C. and BROMLEY, R. (eds) (1977): Casual Work and Poverty in Third World Cities. John Wiley, Chichester.

GHERTNER, D.A. (2011): 'Rule by aesthetics: world-class city making in Delhi', in ROY A. and ONG A. (eds.): Worlding Cities: Asian Experiments and the Art of Being Global. WileyBlackwell Oxford, pp. 279-306.

GOSPODINI, A. (2006): 'Portraying, classifying and understanding the emerging landscapes in the post-industrial city', Cities 23(5): 311-330.

GUEYE, C. (2001): 'Touba: the new Dairas and the urban dream', in TOSTENSEN, A. TVEDTEN, I. and VAA, M. (eds): Associational Life in African Cities: Popular Responses to the Urban Crisis. Nordiska Afrikainstitutet, Uppsala, pp 107-123.

HART, K. (1970): 'Small-scale entrepreneurs in Ghana and development planning', Journal of Development Studies 6(4): 104-120. 
HART, K. (1973): 'Informal income opportunities and urban employment in Ghana', Journal of Modern African Studies 11(1): 61-89.

HARVEY, D. (1989): 'From managerialism to entrepreneurialism: the transformation in urban governance in late capitalism', Geografiska Annaler Series B: Human Geography 71(1): 3-13.

HOLSTON, J. (2011): Insurgent Citizenship: Disjunctions Of Democracy And Modernity in Brazil. Princeton University Press, Princeton.

ILO (International Labour Organisation) (1972): Employment, Income and Equality: A Strategy for Increasing Productive Employment in Kenya. ILO, Geneva.

JIMU, I.M. (2005): 'Negotiated economic opportunity and power: perspectives and perceptions of street vending in urban Malawi' Africa Development 30(1): 35-51

JUSTGIVING (2001): Demolition of shacks stopped by charity campaign [online resource]. URL http://justgiving.com/category/Inter.../?ArticleType [Accessed 20 November 2001].

KAMETE, A.Y. (2002a): The Nature, Extent and Eradication of Homelessness in Zimbabwe. University of Newcastle upon Tyne, CARDO.

KAMETE, A.Y. (2002b): Governance for Sustainability?—Balancing Social and Environmental Concerns in Harare. Christian Michelsen Institute, Bergen.

KAMETE, A.Y. (2009) 'In the service of tyranny: debating the role of planning in Zimbabwe's urban `clean-up' operation', Urban Studies, 46(4): 897-922.

KAMETE, A.Y. and LINDELL, I. (2010): "The politics of "non-planning" interventions in African cities: unravelling the international and local dimensions in Harare and Maputo', Journal of Southern African Studies 36(4): 889-912.

KAYUNI, H.M. and TAMBULASI, R.I.C. (2009): 'Political transitions and vulnerability of street vending in Malawi', Theoretical and Empirical Researches in Urban Management 3(1): 79-96.

KING, K. (2001): ‘Africa’s informal economies: thirty years on', SAIS Review 21(1): 97-108. 
LAGANPARSAD, M. (2010): 'Metro police deny charges of street children abuse', Sunday Times. Johannesburg, 14 February.

LEDUKA, R.C. (2002): 'Contested Urban Space: the local state versus street traders in Maseru's CBD West'. Paper presented at the conference 'Gender, Markets and Governance', Bamako, 712 September.

LEGG, S. (2007): 'Beyond the European province: Foucault and postcolonialism', in. CRAMPTON J.W. and ELDEN, S. (eds): Space, Knowledge and Power: Foucault and Geography. Ashgate, Aldershot, pp. 265-289.

LINDELL, I. (2008): 'The multiple sites of urban governance: insights from an African city', Urban Studies 45(9): 1879-1901.

LINDELL, I. (2010): 'Introduction: the changing politics of informality - collective organising, alliances and scales of engagement', in LINDELL, I. (ed): Africa's Informal Workers: Collective Agency, Alliances and Transnational Organizing in Urban Africa. Nordiska Afrikainstitutet/Zed Books, Uppsala/London, pp. 1-30.

LLOBERA, J.R. (1988): 'The dark side of modernity', Critique of Anthropology 8(2): 71-76.

MALONEY, W.F. (2004): 'Informality revisited', World Development 32(7): 1159-1178.

MAPONGA, V. (2006): 'Heavy security at camp for street children', The Standard. Harare, 3 March.

MARCUSE, H. (1969): 'Repressive tolerance', in WOLFF, R.P., MOORE Jr, B. and MARCUSE, H. (eds): A Critique of Pure Tolerance. Beacon Press, Boston, pp. 95-137.

MASHAVIRA, R. (1999): 'Zimbabwe's housing backlog hits one million', Daily Mail \& Guardian. Johannesburg, 19 July.

MEAGHER, K. (2010): Identity Economics: Social Networks and the Informal Economy in Nigeria. James Currey, Suffolk. 
METH, P. (2010): 'Unsettling insurgency: reflections on women's insurgent practices in South Africa', Planning Theory \& Practice 11(2): 241-263.

MISZTAL, B.A. (2001): 'Trust and cooperation: the democratic public sphere', Journal of Sociology 37(2): 371-386.

MISZTAL, B.A. (2005): 'The new importance of the relationship between formality and informality', Feminist Theory 6(4): 173-194.

MOOYA, M.M. and CLOETE, C.E. (2007): 'Property rights, land markets, and poverty in Namibia's "extra-legal" settlements: an institutional approach', Global Urban Development, 3(1): 1-23.

MOSER, C.O.N. (1978): 'Informal sector or petty commodity production: dualism or dependency in urban development?' World Development 6 (9-10): 1041-1064.

MPSLSW (Ministry Of Public Service Labour and Social Welfare) (1999): Action Plan: Targeting street children-A project proposal for the removal of children from the streets to places of safety throughout Zimbabwe. MPSLSW, Harare.

MPSLSW (Ministry of Public Service Labour and Social Welfare) (2000): Study on street children in Zimbabwe. MPSLSW, Harare.

MUBVAMI, T. and HALL, N. (2000): City Consultations: Urban Poverty in Harare. Municipal Development Programme, Harare.

NCHITO, W. (2002): 'New markets, new practices: a study of the management of a new market in Lusaka, Zambia'. Paper presented at the conference on 'Gender, Markets and Governance', Bamako, 7-12 September.

ODENDAAL, N. (2007): 'The Cato Manor Development Project in Durban, South Africa', American Behavioral Scientist 50(7): 935-945.

POPKE, E.J. and BALLARD, R. (2004): 'Dislocating modernity: Identity, space and representations of street trade in Durban, South Africa', Geoforum, 35(1): 99-110. 
POTTS, D. (2006): "Restoring order"? Operation Murambatsvina and the urban crisis in Zimbabwe', Journal of Southern African Studies 32(2): 273-291.

PRAKASH, G. (ed.) (2010): Noir Urbanisms: Dystopic Images of the Modern City. Princeton University Press, Princeton.

RAKODI, C. (1993): 'Planning for whom?' In Devas, N. and Rakodi, C. (eds): Managing Fast Growing Cities: New Approaches to Urban Planning and Management in the Developing World. Longman, Harlow, pp. 208-235.

RAKODI, C. (2006): 'Relationships of power and place: the social construction of African cities', Geoforum 36(3): 312-317.

ROBINS, S. (2002): 'Planning "suburban bliss” in Joe Slovo Park, Cape Town', Africa 72(2): $511-548$.

ROY, A. (2003): 'Paradigms of propertied citizenship: transnational techniques of analysis', Urban Affairs Review 3(4): 463-491.

ROY, A. (2008): Calcutta Requiem: Gender and the Politics of Poverty. Pearson, New Delhi.

ROY, A. (2010): 'Informality and the politics of planning', IN HILLIER J. and HEALEY, P. (eds): The Ashgate research companion to planning theory: conceptual challenges for spatial planning Ashgate, Aldershot, pp. 87-107.

ROY, A. (2011): 'Slumdog cities: rethinking subaltern urbanism' International Journal of Urban and Regional Research 35(2): 223-238.

ROY, A., and ALSAYYAD, N. (eds) (2004): Urban Informality: Transnational Perspectives From the Middle East, Latin America and South Asia. Lexington, Lanham, MD.

RUPIYA, M. (2005): 'Zimbabwe: Governance through military operations', African Security Review 14(3): 117-118.

SABOLA, T (2006): 'Vendors eviction: who benefits?' The Nation (Malawi) [online resource] URL http://www.nationmalawi.com/articles.asp?articleID=16423 [Accessed 28 April 2007]. 
SAMERS, M. (2005): "The myopia of "diverse economies", or a critique of the "informal economy", Antipode 37(5): 875-886.

SANDERCOCK, L. (1998): Towards Cosmopolis: Planning for Multicultural Cities. John Wiley, Chichester.

SHACKDWELLERS INTERNATIONAL (2001): 'Zimbabwe' [online resource]. URL http://www.dialogue.org.za/sdi/zimbabwe.htm Accessed 30 November.

SHACKDWELLERS INTERNATIONAL (2007): 'Report on the Swaziland expedition/ South Africa-Zambia exchange visit to Mbabane 14/09/2007-17/09/2007' [online resource]. URL http://www.sdinet.org/static/upload/documents/revisiting_savings_in_swaziland_a_south_africa ,_nambia_exchange.pdf [Accessed 13 may 2011].

SIMONE, A. (2002): 'The dilemmas of informality for African governance', in PARNELL, S., PIETERSE, E., SWILling, M. and WOOLDRIDGE, D. (eds): Democratising Local Government: The South African Experiment. University of Cape Town Press, Cape Town, pp. 294-304.

SIMONE, A. (2005a): For the city yet to come: changing African life in four cities. Duke University Press, Durham

SIMONE, A. (2005b): 'Introduction: urban processes and change', in SIMONE, A. and ABOUHANI, A. (eds): Urban Africa: Changing Contours of Survival in the City. CODESRIA/Zed Books, Dakar/London, pp. 1-26.

SIMPOSYA, M.A. (2010): 'Towards a sustainable upgrading of unplanned urban settlements in Zambia [online resource]. URL http://www.urbanlandmark.org.za/conference/2010_abstracts/abstract_simposya.pdf (Accessed 15 March 2011).

STERN, R.E. and BARBOUR, P.A. (2005): Designing a Small Business Tax System that Enhances Growth: Lessons from Africa. World Bank, Washington, DC.

STREN, R.E. and WHITE R.R. (1989): African Cities in Crisis: Managing Rapid Urban Growth. Westview Press, Boulder, CO. 
SWILLING, M., SIMONE, A. and KHAN, F. (2002): "My soul I can see": the limits of governing Africa cities in a context of globalisation and complexity', in PARNELL, S., PIETERSE, E., SWILLING, M. and WOOLDRIDGE, D. (eds): Democratising Local Government: The South African Experiment. University of Cape Town Press, Cape Town, pp. 305-327.

THOMAS, J. (2001): ‘What is the informal economy, anyway?’ SAIS Review 21(1): 1-11.

TIBAIJUKA, A.K. (2005): Report of the fact-finding mission to Zimbabwe to assess the scope and impact of Operation. United Nations, New York.

TIPPLE, A.G. (2000): Extending Themselves: User-Initiated Transformations of GovernmentBuilt Housing in Developing Countries. Liverpool University Press, Liverpool.

TOKMAN, V.E. (2001): 'Integrating the informal sector into the modernization process', SAIS Review 21(1): 45-60.

TOLSI, N. (2010): 'Rounded up and shipped out', Mail and Guardian. Johannesburg, 22 January.

UN-HABITAT (2008): UN-HABITAT and the Kenya Slum Upgrading Programme Strategy Document. UN-HABITAT, Nairobi.

UN-HABITAT (2010) Global Report on Human Settlements 2009: Planning Sustainable Cities. UN-HABITAT/Earthscan, Nairobi/London.

VAA, M. and TRANBERG-HANSEN, K. (eds) (2004): Reconsidering Informality: Perspectives from Urban Africa. Nordiska Afrikainstitutet, Uppsala.

WATSON, V. (2002): Change and Continuity in Spatial Planning: Metropolitan Planning in Cape Town under Political Transition. Routledge, London.

WATSON, V. (2009): “"The planned city sweeps the poor away. . .": urban planning and 21st century urbanisation, Progress in Planning, 72(3): 151-193. 
WEKWETE, K.H. (1988): 'Development of urban planning in Zimbabwe: an overview', Cities 5(1): 57-71.

YIFTACHEL, O. (2002): 'The dark side of modernism: planning as control of an ethnic minority', in BRIDGE, G. and WATSON, S. (eds): The Blackwell city reader. Blackwell, Malden, MA, pp. 535-541. 